Article

\title{
Aligned Sustainability Understandings? Global Inter-Institutional Arrangements and the Implementation of SDG 2
}

\author{
Helmut Breitmeier *, Sandra Schwindenhammer, Andrés Checa, Jacob Manderbach and Magdalena Tanzer \\ Department of Political Science, Justus Liebig University Giessen, 35394 Giessen, Germany; \\ E-Mails: helmut.breitmeier@sowi.uni-giessen.de (H.B.), sandra.schwindenhammer@sowi.uni-giessen.de (S.Sch.), \\ andres.checa@sowi.uni-giessen.de (A.C.), jacob.b.manderbach@sowi.uni-giessen.de (J.M.), \\ magdalena.tanzer@sowi.uni-giessen.de (M.T.) \\ * Corresponding author
}

Submitted: 17 August 2020 | Accepted: 20 November 2020 | Published: 26 February 2021

\begin{abstract}
This article asks whether inter-institutional arrangements (IIAs) can facilitate norm understandings of sustainability in the global food regime complex to ensure the implementation of SDG 2. It refers to theories of norm implementation and regime complexes and focuses on two explanatory factors: non-material resources (authority and knowledge) and interplay management (participation and interaction). The article deals with three case studies: The Codex Alimentarius Commission, the Sustainable Food Systems Programme, and the Standards and Trade Development Facility. Qualitative empirical analysis is based on documents and expert interviews. The article assumes that both explanatory factors are beneficial for the development of an aligned sustainability understanding. The findings indicate that IIAs serve as discursive fora for institutional exchange and can, thus, facilitate the development of aligned sustainability understandings in the global food regime complex. However, the article also identifies some structural factors that provide more scope for certain actors to enforce their normative views and interests, which ultimately hampers the implementation of SDG2.
\end{abstract}

\section{Keywords}

authority; food regime complex; inter-institutional arrangements; interplay management; SDG implementation; sustainability understandings

Issue

This article is part of the issue "The 2030 Agenda for Sustainable Development: Transformative Change through Sustainable Development Goals?" edited by Thomas Hickmann (University of Utrecht, The Netherlands), Markus Lederer (Technical University of Darmstadt, Germany), Jens Marquardt (Technical University of Darmstadt, Germany), Sandra Schwindenhammer (Justus Liebig University Giessen, Germany) and Sabine Weiland (Catholic University of Lille, France).

(C) 2021 by the authors; licensee Cogitatio (Lisbon, Portugal). This article is licensed under a Creative Commons Attribution 4.0 International License (CC BY).

\section{Introduction}

In 2015, the United Nations General Assembly adopted 17 Sustainable Development Goals (SDGs) as part of the global 2030 Agenda for Sustainable Development, which have since served as the global normative reference framework for sustainability. SDG 2 stipulates to "[e]nd hunger, achieve food security and improved nutrition and promote sustainable agriculture" (United Nations, 2015, p. 14). Yet, sustainability is a vague norm that is "subject to continuous argument over its true meaning and practical implications" (Meadowcroft et al., 2019 , p. 2). As revealed by studies on global agri-food governance, the norm's flexibility can facilitate the development of different norm understandings and cause "disjointed" political discourses, "in which advocates of different [sustainability] models talk past one another and fail to fully engage in productive dialogue on pathways forward" (Clapp \& Scott, 2018, p. 4). Referring to studies on policy implementation (Jager, Newig, Challies, \& Kochskämper, 2020), this article argues that different norm understandings of sustainability 
impede SDG 2 implementation. The article builds on research in international relations (IR) theory on the impact of different norm understandings in global goal implementation (Alger \& Dauvergne, 2020; Breitmeier, Schwindenhammer, Checa, Manderbach, \& Tanzer, 2020) and the role of inter-institutional cooperation in ensuring the effectiveness of global regime complexes (Biedenkopf, 2017; Gehring \& Faude, 2013). It does not examine how SDG 2 is implemented but analyzes the potential of global inter-institutional interaction to achieve more aligned sustainability norm understandings, which we consider a crucial prerequisite for SDG 2 implementation. To this end, the analysis focuses on inter-institutional arrangements (IIAs) which provide discursive exchange fora and "facilitate cooperation between social actors when they do not share common views and interests" (Compagnon \& Bernstein, 2017, p. 815). The article asks: Can IIAs in the global food regime complex facilitate more aligned norm understandings of sustainability to ensure the implementation of SDG 2? In doing so, the article contributes to ongoing debates on factors that promote and sustain interinstitutional interaction (e.g., Biermann \& Koops, 2017).

The article conducts a qualitative comparative case study analysis of three IIAs concerned with sustainability issues related to global agri-food governance-the Codex Alimentarius Commission (CAC), the Sustainable Food Systems Programme (SFSP), and the Standards and Trade Development Facility (STDF). The analysis focuses on two explanatory factors-non-material resources (authority and knowledge) and interplay management (participation and interaction)-which can be considered crucial for inter-institutional interactions and sustainability discourses and which IIAs seek to mobilize to ensure more aligned norm understandings.

First, the article illustrates the theoretical framework that draws on norm implementation theory and regime complex theory (Section 2). After describing the data and methods applied (Section 3), the article presents and discusses empirical findings from a qualitative comparative case study analysis of CAC, SFSP, and STDF (Section 4). Finally, we draw conclusions and outline future areas of research (Section 5).

\section{Theoretical Framework}

According to Margulis (2013), the current global food system constitutes a global regime complex, which is defined as a non-hierarchical "loosely coupled set of specific regimes" (Keohane \& Victor, 2011, p. 7). Each specific regime is organized around "sets of implicit or explicit principles, norms, rules, and decision-making procedures, around which actors' expectations converge in a given area of international relations" (Krasner, 1982, p. 186). Breitmeier, Young, and Zürn (2006, p. 4) expand this definition by stressing that principles, norms, and rules "give rise to social practices." Although regime complexes can become embedded in overarching norms
(Zelli, Gupta, \& van Asselt, 2013), they leave room for different norm understandings. Accordingly, these different norm understandings might collide and cause problems and negative spillovers such as policy incoherence (Biedenkopf, 2017). Regime complex theory allows focusing on the intricate and interdependent interactions and analyzing a regime complex' problem-solving capacity (Breitmeier, 2018).

The global food regime complex is weak and fragmented and incorporates regimes from different issue areas, such as agriculture and food, international trade, or global human rights (Margulis, 2013). It involves various actors, such as states, non-governmental organizations (NGOs), transnational corporations (TNCs), and international organizations (IOS). Actors in the global food regime complex follow different sustainability understandings (Breitmeier et al., 2020), which leads to diverging food policies and impedes the fight against hunger (Margulis, 2013) and, thus, the implementation of SDG 2. In addition, the weak and fragmented character of the global food regime complex strengthens the asymmetric power structure (Drezner, 2009) in global agri-food governance that enables powerful states, international institutions, and TNCs to shape the global food agenda according to their interests and sustainability understandings. Conversely, less powerful actors such as NGOs or people's movements are widely disadvantaged (Clapp, 2018; Margulis, 2018; McKeon, 2018). This became particularly evident in the debates on global food policy in the context of the 2007/2008 food crisis, in which TNCs successfully re-legitimized the productionist agenda despite its negative environmental and social impacts (Fouilleux, Bricas, \& Alpha, 2017).

Norms entail a dual quality since "they are both structuring and socially constructed through interaction in a context" (Wiener, 2007, p. 49). Consequently, norms are not stable, and their content can be subject to different interpretations. However, IR norm researchers convincingly argue that the existence of different understandings of international norms does not per se have a negative impact on norms. Different norm understandings increase the potential of norm contestation, which is "the condition for a shared understanding over meanings of norms" and "can generate norm legitimacy" (Deitelhoff, 2020, p. 3; see also Deitelhoff \& Zimmermann, 2020; Wiener, 2014). As Jager et al. (2020) show, shared norms and norm understandings have a positive effect on the implementation of policy outputs. They can accelerate a "shared sense of purpose and provide favorable conditions for effective problem solving" (Jager et al., 2020, p. 387). At best, shared norms and norm understandings can also support cooperative actions among different stakeholders (Ostrom, 1990). Therefore, we argue that despite the fact that regime complexes will "always exhibit a degree of divergence regarding the principles, norms, rules, or procedures of their elemental regimes" (Orsini, Morin, \& Young, 2013, p. 29), an aligned sustainability understanding within the 
food regime complex is a crucial prerequisite for SDG 2 implementation.

Schwindenhammer, Breitmeier, and Kirf (2017) observe an increasing number of IIAs engaged in sustainability issues in the global food regime complex. We define IIAs as formalized and discursive exchange fora in which at least two actors of the global food regime complex participate. IIAs can foster cooperation among these actors even if they pursue different interests and (sustainability) understandings (Compagnon \& Bernstein, 2017; Stokke \& Oberthür, 2011). Consequently, we consider IIAs as an institutionalized form of a regime complex' problem-solving capacity and as potential fora for facilitating aligned sustainability understandings. Although most IIAs do not make legally binding decisions, they serve as important discursive fora that bring together different types of actors. Moreover, many IIAs in the global food regime complex follow a multi-stakeholder approach and are open to governmental agencies, IOs, NGOs, TNCs, and scientific institutions. In this way, IIAs can enable actors who are disadvantaged by the asymmetric power structure of the global food regime complex (Margulis, 2013) to raise their voices and can strengthen vertical cooperation (Hickmann et al., 2020). While some IIAs explicitly aim to develop a common sustainability understanding, others intend to develop at least a minimum consensus. However, to date, there is no clear model of how IIAs work, nor do we know which factors determine the outcome of an IIA. According to Biermann and Koops (2017, p. 22), there is a general research gap in "identifying and isolating the key factors influencing the formation and maintenance of cooperative relations."

This article assumes that factors at IIA-level impact the development of aligned sustainability norm understandings. The analysis focuses on two explanatory factors at the structural level of an IIA: non-material resources (authority and knowledge) and interplay management (participation and interaction). Based on research on authority pooling and the co-production of sustainability knowledge, the first assumption is that an IIA is more likely to develop an aligned sustainability understanding when different authority sources and knowledge systems are represented. The second assumption is that an IIA is particularly suitable to foster processes of norm alignment when it involves interplay management. We are aware that the conceptual focus on IIAs can only shed light on a small part of inter-institutional interaction in the food regime complex. In addition, it should be kept in mind that interorganizational relations are not a panacea for the management of potential norm conflicts. It is also possible that IIAs maintain or facilitate the formation of rivalries and conflicts (Biermann \& Koops, 2017).

\subsection{Explanatory Factor I: Non-Material Resources}

Authority and knowledge are important non-material resources for (sustainability) discourses. On an individu- al level, they can provide actors with discursive power and the ability to set and steer a discourse and persuade other actors of a certain sustainability understanding (Milkoreit, Bansard, \& van der Hel, 2020). On a collective level, the representation and combination of different types of authority and knowledge systems can facilitate the development of an aligned and practically implementable sustainability understanding (Norström et al., 2020; Tengö, Brondizio, Elmqvist, Malmer, \& Spierenburg, 2014).

Focusing on the latter, we differentiate between three types of authority: (1) moral authority; (2) technical authority; and (3) legal authority (see Schwindenhammer, 2016). Moral authority is based on the credibility with which actors pursue goals in the public interest (Lipschutz \& Fogel, 2002, p. 125) and is attributed in particular to NGOs (Hall \& Biersteker, 2002). Technical authority rests on the promise of more rational policy outcomes by providing knowledge-based expertise (Flohr, Rieth, Schwindenhammer, \& Wolf, 2010) and can be exercised by each actor with knowledge and expertise in the given issue area. Legal authority "refers to the constitutionally institutionalized delegation of competencies by democratic procedures and is, thus, exclusively exercised by public actors" (Schwindenhammer, 2016, p. 106).

Regarding knowledge, we differentiate between three knowledge systems: (1) local knowledge; (2) scientific knowledge; and (3) expert knowledge. While local knowledge systems include traditional and indigenous knowledge based on informal and everyday interpretations, scientific knowledge refers to systematically recorded knowledge in an academic context (Raymond et al., 2010). NGOs are considered representatives of local knowledge at the international level (Sändig, Bernstorff, \& Hasenclever, 2018), whereas academic institutions represent scientific knowledge. Expert knowledge refers to highly specialized knowledge in a given issue area. In particular IOs, NGOs, and (transnational) corporations are considered representatives of this knowledge system (Breitmeier \& Hansel, 2015; Schwindenhammer, 2020).

We are aware that the different types of authority are analytical ideal types and, although they have to be analyzed separately, they might occur in mixed forms empirically. For instance, transnational biotechnology companies have successfully pooled moral and technical authority to influence the global rise and regulation of genetically modified insect technology in global agriculture (Schwindenhammer, 2020). Similarly, transnational NGOs simultaneously exercise moral authority by reference to the global right to food and technical authority through the provision of scientific expertise to influence agri-food governance (Schwindenhammer, 2016). In addition, Tortajada (2016) emphasizes that NGOs perform a wide range of functions in different policy areas and do not necessarily only pursue goals in the public interest. The same applies to the representation of 
local knowledge. NGOs are professionalized organizations whose staff often have an academic background. They receive "their legitimacy from benevolence and effectiveness in improving other peoples' lives and in promoting 'common interests"' but, often located in the Global North, "remain too disconnected from the affected grassroots" and "have only weak ties with the populations on whose behalves they claim to act" (Sändig, Bernstorff, \& Hasenclever, 2018, p. 590; see also Brühl, 2010). Consequently, our framework is open to other types of civil society organizations such as grassroots organizations, people's movements, or affected persons' organizations.

\subsection{Explanatory Factor II: Interplay Management}

Interplay management refers to "conscious efforts by any actor or group of actors, in whatever form or forum, to address and improve institutional interaction and its effects" (Stokke \& Oberthür, 2011, p. 6). Since regime complexes are the result of a growing density and complexity of partly overlapping institutions (Raustiala \& Victor, 2004), interplay management may also serve as an instrument to prevent and reduce conflicts. Interplay management can be regulatory, in the sense of determining standards of behavior, or enabling, by facilitating learning and capacity building (Oberthür, 2009). We consider two aspects of interplay management to be crucial for IIAs: (1) participation, and (2) interaction. Both aspects might also serve as mechanisms to reduce unequal distribution of material and nonmaterial resources among different actor groups.

Regarding participation, Gehring and Faude (2013, p. 121) note that "regime complexes are usually not purposively established by a clearly determined membership." Therefore, questions of inclusion and exclusion are critical also for IIAs. Especially in the field of global food governance, McKeon (2015, p. 328) critically observes that "public responsibility has been progressively sold out to markets and corporations while the front-line actors of food provision-families, communities, and small-scale producers-have been disempowered." On the one hand, IIAs should, therefore, include members from various actor groups and scales, which would create "social representativeness" that could build "bridging ties with groups having different characteristics" (Morin, Louafi, Orsini, \& Oubenal, 2017, p. 544). On the other hand, all actors must be in the position to equally contribute to the work of the IIA, for example by providing oral or written inputs during meetings of the highest decision-making body. The numerical and practical participation of different actor groups in IIAs enhances the potential to shift the discourse on sustainability towards an aligned understanding.

Biermann (2008, p. 161) lists four characteristics for inter-institutional interaction: "(1) regular, intense contacts; (2) formal and informal rules of behavior; (3) regular channels of cooperation of varying formalization; and
(4) long-term orientation as opposed to ad hoc cooperation." While regular exchange between staff on the operational level is important to gain understanding of other actors' cultures and modi operandi, frequent interaction might also be an indicator for a vital and strong relation. Biermann (2008) also notes that the quality of interplay management stems from the quality of interinstitutional ties rather than their quantity. Other key aspects are the preparation and the strategic focus of meetings and their outputs (Biermann \& Koops, 2017). Stokke $(2020$, p. 209) points to the important aspect that "interplay management does not necessarily imply harmonious orientation towards synergetic outcomes," which directs attention of research also to potentially diverging objectives and norm understandings. In order to develop an aligned sustainability understanding, an IIA needs to provide a high level of interaction between its members. This is ensured by regular and clearly focused meetings of the decision-making bodies as well as of the working groups.

\section{Methods and Data}

The comparative qualitative analysis builds on official documents and expert interviews (a list of documents and interviews is provided in the Supplementary File). The 38 analyzed documents published by the IIAs were selected for their strategic importance and reference to the issues of sustainability and food. The document data base includes terms of reference documents and strategic plans, annual reports, meeting reports, and work plans. Additionally, 19 expert interviews with representatives from the IIAs from different member groups-secretariats, IOs, national governments and public agencies, and the private sector-were conducted between February and September 2020. For each IIA, the interviews cover at least one representative per member group to obtain a comprehensive picture. The interviews were guided by a semi-structured questionnaire that included questions on the IIA's sustainability understanding as well as on the two explanatory factors non-material resources and interplay management. Further expert interviews with 10 representatives conducted between May and October 2019 serve as empirical background information.

The resulting texts-documents and transcribed interviews - were deductively analyzed (1) to identify the IIAs' sustainability understandings and (2) to assess the explanatory factors non-material resources and interplay management. By means of a coding system that builds upon the theoretical framework, the analysis of sustainability understandings provides an insight into the IIA's reference to the SDGs and to the environmental, economic, and social dimensions of sustainability. For the assessment of non-material resources, references to moral, technical, and legal authority as well as to local, scientific, and expert knowledge systems are identified. Regarding interplay management, the 
analysis explores comprehensive representations of participants and the equal opportunity to contribute (participation) as well as for regular, clearly focused meetings of the highest decision-making bodies and other working groups (interaction).

\section{Results and Discussion}

The three selected case studies-the CAC, the SFSP, and the STDF-represent central IIAs in the global food regime complex. They bring together key actors from different actor groups to work on issues related to food and sustainability.

\subsection{IIA Sustainability Understandings}

The CAC, which was established by the Food and Agriculture Organization (FAO) and the World Health Organization (WHO) in 1963, follows the mission to "[p]rotect consumer health and promote fair practices in the food trade by setting international, science-based food safety and quality standards" (FAO \& WHO, 2019, p. 7). The CAC is the responsible body for implementing the joint FAO/WHO Food Standards Programme. It embraces 188 member states, the European Union as member organization, and 236 observers from intergovernmental and non-governmental organizations. While observers are invited to participate in the standardsetting procedure, for example by providing discussion papers or written comments, the member states are the ones to decide. The resulting standards, codes of practice, and guidelines are collected in the Codex Alimentarius. Although the Codex texts adopted during the annual CAC meetings are not legally binding, they serve as reference for the World Trade Organization's (WTO) Sanitary and Phytosanitary Standards (SPS) Agreement and Technical Barriers to Trade Agreement to solve trade disputes (FAO \& WHO, 2019, p. 2). Subsidiary bodies of CAC are the Codex secretariat, the executive committee, ten general subject committees, six commodity committees, and six FAO/WHO regional coordinating committees. While the Codex' mandate explicitly refers to food safety, sustainability has not yet been a key issue for the organization. The SDGs only made it onto the agenda in 2017, when the executive committee started developing the new strategic plan (CAC, 2017, p. 10). Eventually, SDGs 2, 3, 12, and 17 were included in the strategic plan 2020-2025. Currently, the Codex committee on general principles is considering the development of indicators for monitoring the results of the Codex' contribution to the SDGs. In this context, a discussion paper that will be considered in the next session in February 2021 recommends reaffirming the importance of the SDGs and further enhancing and communicating the Codex' contribution (CAC, 2020).

The SFSP is a multi-stakeholder partnership that was established in 2015. It is a sub-program of the UN One Planet Network which was formed to implement the 10 Year Framework on Sustainable Consumption and Production. The SFSP aims to "accelerate the shift towards more sustainable food systems" (SFSP, 2017a, p. 1). To this end, SFSP pursues five objectives at global, regional, and national levels: (1) Raising awareness; (2) building capacity; (3) access to and exchange of knowledge; and (4) strengthening synergies and cooperation among food system stakeholders. Up to 23 stakeholders from five clusters (government agencies -7 seatsIOs, NGOs, private sector, and scientific institutions4 seats each) are represented in SFSP's Multi-Stakeholder Advisory Committee (MAC) and participate in its meetings on an equal footing. The MAC is responsible for the overall coordination, implementation, monitoring, and resource mobilization and is the place for strategic discussions and decision-making. The co-leads, elected from the MAC, guide the program's implementation, support the overall coordination, provide financial and/or in-kind contribution, and raise funds. Additionally, there is a task force for each SFSP objective. As SFSP was established in the context of the 2030 Agenda, it is closely linked to the SDGs and supports their implementationespecially SDGs 2 and 12. Furthermore, SFSP emphasizes a holistic sustainability understanding by taking all three dimensions of environmental, economic, and social sustainability into account (SFSP, 2019). In the seventh MAC meeting, SFSP members decided to develop a knowledge tool/lighthouse product to promote a "common understanding of central notions and concepts" (SFSP, 2017b, p. 4). The publication of a glossary of key terms on sustainable food systems was planned for February 2019. However, at the time of writing, the glossary has not yet been published.

The STDF is a global partnership established by WTO, FAO, WHO, World Bank, and World Organization for Animal Health during the fourth Doha Ministerial Conference in 2001. One of its principal goals is to support and finance the implementation of the WTO SPS Agreement in local agricultural projects, promoting food safety and food security in the Global South. Regarding international SPS requirements, STDF is mandated to increase "awareness, mobilize resources, strengthen collaboration, identify and disseminate good practice" (STDF, 2015, n.p.), acting as a knowledge sharing platform and bringing together stakeholders across the agriculture, health, trade, and development sectors. STDF is composed of five founding IOs, six selected developing country experts, several government agencies, and a large number of donors currently contributing funds for the implementation of STDF projects and initiatives. The STDF structure is divided into its secretariat, policy committees, and working groups. STDF also cooperates with a wide network of NGOs, private partners, and observers such as CAC. Since 2017, STDF's work has been increasingly aligned with the 2030 Agenda. Interview data indicate that this strategic step was initiated by an external evaluation. STDF does not only consider itself an active supporter and contributor to a large number 
of SDGs-such as SDGs 2, 3, 5, 8, 10, 12, and 17-but has also adjusted its new medium-term strategy to the 2030 Agenda (STDF, 2020). However, the last STDF metaevaluation, which analyzes the impact of STDF's food projects, states that the IIA still scores low on sustainability (STDF, 2018, p. 2). STDF addresses food by linking it to "safe trade" and access to international agricultural markets, based on the "vision of sustainable economic growth" (STDF, 2020, p. 8). Therefore, it strongly emphasizes the economic sustainability dimension.

\subsection{Assessing the Explanatory Factors}

Table 1 provides an overview of the empirical findings regarding the explanatory factors non-material resources and interplay management.

All types of authority are represented in the three IIAs since they include the respective actor types. However, interviews reveal that some actors do not fit into this typology in practice. In SFSP and STDF, for instance, NGOs do not consider themselves to exercise moral, but rather technical authority. Consequently, moral authority is underrepresented in the IIAs' discourse on sustainability. Although the institutional design of SFSP and STDF includes different types of authority exerted by different types of actors, technical authority dominates the discourses in both IIAs.

Similarly, some knowledge systems are more dominant than others. Contrary to SFSP's aim to heed local needs, e.g., of indigenous people, interview data show that local knowledge is de facto underrepresented in the MAC. In addition, interviewees state that discussions in the MAC tend to ignore important local developments such as the increasing activities of cities regarding sustainable urban food systems. CAC's risk assessment work is exclusively based on scientific knowledge.
One interviewee pointed out that the expertise of Codex members representing the industry is hardly included in the standard-setting procedure, although it is crucial for implementing the adopted standards. Besides, particularly European CAC members call for the inclusion of factors other than science, such as cultural or moral, for the development of standards. The consideration of such factors could lead to a more balanced representation of knowledge systems in CAC, since they rather address local and expert knowledge. While STDF's agricultural projects may incorporate local knowledge depending on the context and through its developing country experts, IOs, and strategic partners, it is still underrepresented in the working groups and policy committees. In this regard, interview data reveals that the lack of permanent STDF members such as local actors from developing countries in the working groups and policy committees is an important inhibiting factor for more effective and direct inclusion of local knowledge from the Global South.

All three IIAs aim for comprehensive representation of different actor groups. In practice, factors such as high travel costs and the limited number of available seats in decision-making bodies (SFSP), or the need to offer nationally or even regionally pre-negotiated positions in the meetings (CAC) are obstacles for actors with limited material resources. Funding sources such as the Codex trust fund have increased the participation of developing countries. However, interviewees stress that countries from the Global North are still better represented and more active in CAC. Interview data also reveal that the level of interaction is generally high. Meetings of the decision-making bodies are very structured and well prepared. In SFSP, three out of four MAC meetings per year are held as teleconferences. While this enables all members to participate, interviewees report that these meetings are overly structured and leave only little room for

Table 1. Assessing IIAs' sustainability understandings.

\begin{tabular}{|c|c|c|c|}
\hline & Sustainability Understanding & Non-Material Resources & Interplay Management \\
\hline CAC & $\begin{array}{l}\text { - Late incorporation of SDGs } \\
\text { in strategic plan } \\
\text { - References to economic } \\
\text { and social sustainability } \\
\text { dimensions }\end{array}$ & $\begin{array}{l}\text { - All authority types } \\
\text { represented } \\
\text { - Predominance of scientific } \\
\text { knowledge }\end{array}$ & $\begin{array}{l}\text { - Formalized meetings, structured } \\
\text { by pre-negotiations } \\
\text { - Complex interaction needed to } \\
\text { build alliances }\end{array}$ \\
\hline \multirow[t]{2}{*}{ SFSP } & $\begin{array}{l}\text { - Close institutional link to } \\
\text { SDGs, especially } 2 \text { and } 12\end{array}$ & $\begin{array}{l}\text { - All authority types } \\
\text { represented }\end{array}$ & $\begin{array}{l}\text { - Regular MAC meetings prepared by } \\
\text { co-leads and regular task forces } \\
\text { meetings }\end{array}$ \\
\hline & - Holistic view on sustainability & $\begin{array}{l}\text { - Predominance of scientific } \\
\text { and expert knowledge }\end{array}$ & $\begin{array}{l}\text { - Interaction impeded by lack of } \\
\text { face-to-face meetings }\end{array}$ \\
\hline \multirow[t]{2}{*}{ STDF } & $\begin{array}{l}\text { - Increasing alignment } \\
\text { with SDGs }\end{array}$ & $\begin{array}{l}\text { - All authority types } \\
\text { represented }\end{array}$ & $\begin{array}{l}\text { - Formalized meetings at irregular } \\
\text { intervals, divided into policy } \\
\text { committees and working groups }\end{array}$ \\
\hline & $\begin{array}{l}\text { - Emphasis on economic } \\
\text { sustainability dimension }\end{array}$ & $\begin{array}{l}\text { - Predominance of scientific } \\
\text { and expert knowledge }\end{array}$ & $\begin{array}{l}\text { - Limited interaction due to small } \\
\text { number of meetings }\end{array}$ \\
\hline
\end{tabular}


open debate. In addition, some criticize that the wide range of topics hinders in-depth preparation, especially for those actors who can delegate fewer staff to represent their organization in the MAC. Similarly, the annual CAC meetings are not considered a place for discussion, which is why all positions should be settled in advance. Consequently, member states must develop a national position in agreement with the main national stakeholders and then build alliances with other countries. Smaller working groups are, thus, essential for IIAs to find consensus, which is why the interaction in such groups is even higher. However, STDF working groups and policy committees meet at irregular intervals and at most twice per year, which limits the possibility to talk about new issues.

Regarding the respective IIA sustainability understandings, only SFSP addresses all three sustainability dimensions. In contrast to the other IIAs, SFSP's foundation is closely linked to the 2030 Agenda and the SDGs. In CAC and STDF, the SDG framework was incorporated from outside and was subject to extensive internal debates, as interview data confirms. In CAC, for example, the rather reluctant position towards sustainability stems from diverging interpretations of the IIA's mandate. While some countries prefer sticking to a narrow interpretation that refers only to consumer health protection and fair trade, others are open for a broader perspective that includes environmental sustainability, sustainable consumption and protection, or sustainability as an additional base for standard development.

In addition, non-material resources give more scope to certain actors to influence the IIA's sustainability understandings. While states and their alliances are of special importance in CAC, FAO and UN Environment as founding organizations are the driving forces in SFSP. To strengthen their privileged role, FAO and UN Environment also cooperate intensively beyond official meetings. This helps them find common positions in the MAC, although they pursue gradually different approaches to sustainable food systems. Since STDF follows the WTO governance arrangements, especially the SPS Agreement, WTO is the central actor in this IIA. Consequently, a more active role of moral authority represented by civil society organizations would lead to a more comprehensive consideration of the sustainability norm regarding the environmental and social dimension in the IIAs. For instance, including NGOs that advocate alternative food systems could help IIAs put greater focus on local cultures, traditions, and specific environmental conditions.

The same effect might arise from a more comprehensive inclusion of local knowledge. Even though all three IIAs aim for comprehensive representation and rely on a high level of interaction to achieve their goals, structural hurdles for such comprehensive representation, rigid structures, and a small number of meetings hinder these ambitions. In case of STDF, the highest decision-making body is convened only at the request of one or more STDF members or by decision of the working groups. When the meetings take place, they are characterized by a strong focus on technical aspects concerning the implementation of the SPS Agreement. This institutional setting hampers the continuous development of a comprehensive STDF sustainability understanding.

Overall, the empirical analysis basically confirms findings from IR research on the relevance of IIAs as discursive exchange fora for social actors with different normative views and interests (Compagnon \& Bernstein, 2017, p. 815). The three IIAs under analysis have started working on issues related to sustainability and food in the particular context of the SDGs. Interview data confirm a high willingness for cooperation as well as a high level of commitment among all actor groups represented. However, there are practical and structural limitations which ultimately counteract the development of aligned sustainability understandings in the global food regime complex. Discourses on sustainability mainly focus on technical aspects that can easily be agreed on. In contrast, moral and legal discussions with higher conflict potential seem to be avoided. This is particularly interesting since none of the IIAs provide binding rules for their members. The findings are in line with Stokke (2020, p. 219), who reports that, regarding regulatory governance, "there have been very few cases of coordination beyond exchange of information and joint knowledge building" in regime complexes when actors with partially competing objectives, e.g., of trade and environmental regimes, come together. Our results demonstrate that these impediments to a more ambitious form of interplay management also influence the development of aligned norm understandings.

\section{Conclusions}

The article asked whether IIAs can facilitate more aligned norm understandings of sustainability in the global food regime complex to ensure the implementation of SDG 2. Building on theories on norm implementation and regime complexes, it analyzed three IIAs: CAC, which promotes standards for safe food and fair food trade; SFSP, which aims at more sustainable food systems; and STDF, which supports the implementation of the WTO SPS Agreement in countries of the Global South. The qualitative empirical analysis demonstrated that IIAs have started working on issues related to sustainability and food in the particular context of the SDGs. In addition, it became clear that the two explanatory factors analyzed are, indeed, beneficial for the development of aligned sustainability understandings and are, thus, mobilized by the three IIAs under analysis. The focus on interplay management and non-material resources therefore constitutes a useful analytical lens to further develop IR research on norm implementation through inter-institutional cooperation (Gehring \& Oberthür, 2009; Jager et al., 2020). Expanding regime complex theory by ideational factors, our approach enables us to look at the sustainability norm from a more 
comprehensive perspective and to capture discourses that foster norm development.

However, the development of aligned sustainability understandings still faces some challenges. Even though the IIAs include the SDGs in their work, shared sustainability understandings are still missing. This seems to confirm the argument that international actors often experience difficulties and impediments in inter-institutional interaction when there are diverging interests at stake (Stokke, 2020). Especially in this weak and fragmented food regime complex (Margulis, 2013), the struggle for common norms seems to persist (Orsini et al., 2013) despite the global normative framework of the SDGs. The activities of the three IIAs do not necessarily lead to harmonization or coordination of norm understandings in the food regime complex. This finding underlines the need to analytically focus on a very early stage of the norm implementation process.

The empirical analysis also showed that the IIAs' discourses mainly focus on technical aspects and avoid moral or legal aspects. Further research is needed to address other factors that could explain this current lack of legal and moral authority in IIAs. For instance, future research could investigate whether IIAs avoiding moral aspects has led to a depoliticization of aligned sustainability understandings in the global food regime complex. The detected under-representation of local knowledge in IIAs points to the need for further analyses of how local knowledge and local developments might enter IIAs' discourses through the wider relationships of the actors in an IIA. Especially relations to local people's movements that promote alternative normative frames from the bottom-up, such as La Via Campesina, could provide opportunities for assessing the involvement of local cultural aspects and normative demands of small-scale farmers in IIA discourses. Further research could also investigate relations between IIAs and possible feedback loops from discourse within IIAs to the work of members outside the IIA. Finally, the empirical analysis also revealed that non-material resources give more scope to certain actors in the three IIAs. In this sense, further research could also consider internal power structures and the agency of specific actors and, thus, their ability to steer discourses and influence the aligned sustainability understanding of an IIA.

\section{Acknowledgments}

The research was conducted in the context of the research project 'TANNRE-The Transformation Potential of Inter-Institutional Arrangements and the Norm of Sustainability in the Global Food Regime Complex' (FKZ: 031B0229), funded by the German Federal Ministry of Education and Research. We thank two anonymous reviewers, the guest editors to this special issue, Markus Lederer, and the participants of the conference 'Die Nachhaltigkeitsagenda der Vereinten Nationen: Konzepte, Entstehung und Wirkung der Sustainable
Development Goals,' organized by the DVPW Working Group Environmental Politics and Global Change at Schader-Forum Darmstadt, for valuable comments and suggestions.

\section{Conflict of Interests}

The authors declare no conflict of interests.

\section{Supplementary Material}

Supplementary material for this article is available online in the format provided by the author (unedited).

\section{References}

Alger, J., \& Dauvergne, P. (2020). The translocal politics of environmental norm diffusion. Environmental Communication, 14(2), 155-167.

Biedenkopf, K. (2017). Relations between international organisations in combating climate change. In R. Biermann \& J. A. Koops (Eds.), Palgrave handbook of inter-organizational relations in world politics (pp. 649-677). London: Palgrave Macmillan.

Biermann, R. (2008). Towards a theory of interorganizational networking: The Euro-Atlantic security institutions interacting. The Review of International Organizations, 3(2), 151-177.

Biermann, R., \& Koops, J. A. (2017). Studying relations among international organizations in world politics: Core concepts and challenges. In R. Biermann \& J. A. Koops (Eds.), Palgrave handbook of interorganizational relations in world politics (pp. 1-46). London: Palgrave Macmillan.

Breitmeier, H. (2018). Sektorale Ordnungspolitik im Wandel: Internationale Umweltregime [Sectoral world order politics in change: International environmental regimes]. In M. Albert \& G. Hellmann (Eds.), Ordnung und Regieren in der Weltgesellschaft [Order and governance in world society] (pp. 185-209). Wiesbaden: Springer Fachmedien.

Breitmeier, H., \& Hansel, M. (2015). Nicht-staatliche Akteure und die Effektivität und Legitimität des globalen Regierens [Non-state actors and the efficiency and legitimacy of global governance]. Zeitschrift für Außen-und Sicherheitspolitik, 8 (2), 507-529.

Breitmeier, H., Schwindenhammer, S., Checa, A., Manderbach, J., \& Tanzer, M. (2020). Politicized sustainability and agricultural policy: Comparing norm understandings of international organizations. Journal of Comparative Policy Analysis: Research and Practice. Advance online publication. https://doi. org/10.1080/13876988.2020.1769480

Breitmeier, H., Young, O. R., \& Zürn, M. (2006). Analyzing international environmental regimes: From case study to database. Cambridge, MA, and London: The MIT Press.

Brühl, T. (2010). Representing the people? NGOs in inter- 
national negotiations. In S. Steffek \& K. Hahn (Eds.), Evaluating transnational NGOs: Legitimacy, accountability, representation (pp. 181-199). Basingstoke: Palgrave Macmillian.

CAC. (2017). Report of the seventy-third session of the executive committee of the Codex Alimentarius Commission (No. RREP17/EXEC2). Geneva: CAC.

CAC. (2020). Codex committee on general principles: Discussion paper on monitoring codex results in the context of the Sustainable Development Goals (SDGs) (No. CX/GP 20/32/8). Bourdeaux: CAC.

Clapp, J. (2018). Mega-mergers on the menu: Corporate concentration and the politics of sustainability in the global food system. Global Environmental Politics, 18(2), 12-33.

Clapp, J., \& Scott, C. (2018). The global environmental politics of food. Global Environmental Politics, 18(2), 1-11.

Compagnon, D., \& Bernstein, S. (2017). Nondemarcated spaces of knowledge-informed policy making: How useful is the concept of boundary organization in IR? Review of Policy Research, 34(6), 812-826.

Deitelhoff, N. (2020). What's in a name? Contestation and backlash against international norms and institutions. The British Journal of Politics and International Relations. Advance online publication. https:// doi.org/10.1177/1369148120945906

Deitelhoff, N., \& Zimmermann, L. (2020): Things we lost in the fire: How different types of contestation affect the robustness of international norms. International Studies Review, 22(1), 51-76.

Drezner, D. W. (2009): The power and peril of international regime complexity. Perspectives on Politics, 7(1), 65-70.

FAO, \& WHO. (2019). Codex strategic plan 2020-2025. Rome and Geneva: FAO and WHO.

Flohr, A., Rieth, L., Schwindenhammer, S., \& Wolf, K. D. (2010). The role of business in global governance: Corporations as norm-entrepreneurs. Basingstoke: Palgrave Macmillan.

Fouilleux, E., Bricas, N., \& Alpha, A. (2017). 'Feeding 9 billion people': Global food security debates and the productionist trap. Journal of European Public Policy, 24(11), 1658-1677.

Gehring, T., \& Faude, B. (2013). The dynamics of regime complexes: Microfoundations and systemic effects. Global Governance, 19(1), 119-130.

Gehring, T., \& Oberthür, S. (2009). The causal mechanisms of interaction between international institutions. European Journal of International Relations, 15(1), 125-156.

Hall, R. B., \& Biersteker, T. J. (Eds.). (2002). The emergence of private authority in global governance. Cambridge: Cambridge University Press.

Hickmann, T., van Asselt, H., Oberthür, S., Sanderink, L., Widerberg, O., \& Zelli, F. (2020). Institutional interlinkages. In F. Biermann \& R. E. Kim (Eds.), Architectures of earth system governance. Institutional com- plexity and structural transformation (pp. 119-136). Cambridge: Cambridge University Press.

Jager, N. W., Newig, J., Challies, E., \& Kochskämper, E. (2020). Pathways to implementation: Evidence on how participation in environmental governance impacts on environmental outcomes. Journal of Public Administration Research and Theory, 30(3), 383-399.

Keohane, R. O., \& Victor, D. G. (2011). The regime complex for climate change. Perspectives on Politics, 9(1), 7-23.

Krasner, S. D. (1982). Structural causes and regime consequences: Regimes as intervening variables. International Organization, 36(2), 185-205.

Lipschutz, R. D., \& Fogel, C. (2002). "Regulation for the rest of us?" Global civil society and the privatization of transnational regulation. In R. B. Hall \& T. J. Biersteker (Eds.), The emergence of private authority in global governance (pp. 115-140). Cambridge: Cambridge University Press.

Margulis, M. E. (2013). The regime complex for food security: Implications for the global hunger challenge. Global Governance, 19(1), 53-67.

Margulis, M. E. (2018). Negotiating from the margins: How the UN shapes the rules of the WTO. Review of International Political Economy, 25(3), 364-391.

McKeon, N. (2015). Global food governance in an era of crisis: Lessons from the United Nations Committee on World Food Security. Canadian Food Studies, 2(2), 328-334.

McKeon, N. (2018). Global food governance: Between corporate control and shaky democracy (Global Governance Spotlight No. 2/2018). Bonn: Development and Peace Foundation (sef:).

Meadowcroft, J., Banister, D., Holden, E., Langhelle, O., Linnerud, K., \& Gilpin, G. (2019). Introduction. In J. Meadowcroft, D. Banister, E. Holden, O. Langhelle, K. Linnerud, \& G. Gilpin (Eds.), What next for sustainable development? Our common future at thirty (pp. 1-8). Cheltenham, and Northampton, MA: Edward Elgar Publishing.

Milkoreit, M., Bansard, J. S., \& van der Hel, S. (2020). Agency and knowledge in environmental governance: A thematic review. In M. M. Betsill, T. M. Benney, \& A. K. Gerlak (Eds.), Agency in earth system governance (pp. 86-96). Cambridge University Press.

Morin, J.-F., Louafi, S., Orsini, A., \& Oubenal, M. (2017). Boundary organizations in regime complexes: $A$ social network profile of IPBES. Journal of International Relations and Development, 20(3), 543-577.

Norström, A. V., Cvitanovic, C., Löf, M. F., West, S., Wyborn, C., Balvanera, P., . . Österblom, H. (2020). Principles for knowledge co-production in sustainability research. Nature Sustainability, 3(3), 182-190.

Oberthür, S. (2009). Interplay management: Enhancing environmental policy integration among international institutions. International Environmental Agreements: Politics, Law and Economics, 9(4), 371-391.

Orsini, A., Morin, J.-F., \& Young, O. (2013). Regime com- 
plexes: A buzz, a boom or a boost for global governance? Global Governance: A Review of Multilateralism and International Organizations, 19(1), 27-39.

Ostrom, E. (1990). Governing the commons: The evolution of institutions for collective action. Cambridge: Cambridge University Press.

Raustiala, K., \& Victor, D. G. (2004). The regime complex for plant genetic resources. International Organization, 58(2), 277-309.

Raymond, C. M., Fazey, I., Reed, M. S., Stringer, L. C., Robinson, G. M., \& Evely, A. C. (2010). Integrating local and scientific knowledge for environmental management. Journal of Environmental Management, 91(8), 1766-1777.

Sändig, J., von Bernstorff, J., \& Hasenclever, A. (2018). Affectedness in international institutions: Promises and pitfalls of involving the most affected. Third World Thematics: A TWQ Journal, 3(5/6), 587-604.

Schwindenhammer, S. (2016). Authority pooling and regional organic agriculture standard-setting: Evidence from East Africa. Journal of Environmental Policy \& Planning, 18(1), 102-120.

Schwindenhammer, S. (2020). The rise, regulation and risks of genetically modified insect technology in global agriculture. Science, Technology and Society, 25(1), 124-141.

Schwindenhammer, S., Breitmeier, H., \& Kirf, B. (2017). Die Norm der Nachhaltigkeit im globalen Regimekomplex für Ernährung: anerkannt und doch umstritten [The norm of sustainability in the global regime complex for food: Accepted but still contested]. Zeitschrift für Außen-Und Sicherheitspolitik, 10(3), 353-371.

SFSP. (2017a). Sustainable food systems programme (SFS programme) of the 10-year framework of programmes on sustainable consumption and production (10YFP). Terms of reference (ToR). Paris: SFSP.

SFSP. (2017b). 10YFP sustainable food systems programme: 7th MAC meeting (teleconference). Paris: SFSP.

SFSP. (2019). Collaborative framework for food systems transformation: A multi-stakeholder pathway for sustainable food systems. Nairobi: One Planet.

STDF. (2015). STDF medium-term strategy (2015-2019). Geneva: STDF.

STDF. (2018). Beyond results: Learning the lessons from STDF projects. Geneva: STDF.

STDF. (2020). Medium-term strategy 2020-2024. Geneva: STDF.

Stokke, O. S. (2020). Interplay management. In F. Biermann \& R. E. Kim (Eds.), Architectures of earth system governance: Institutional complexity and structural transformation (pp. 207-232). Cambridge: Cambridge University Press.

Stokke, O. S., \& Oberthür, S. (2011). Introduction: Institutional interaction in global environment change. In S. Oberthür \& O. S. Stokke (Eds.), Managing institutional complexity: Regime interplay and global environmental change (pp. 1-23). Cambridge, MA, and London: The MIT Press.

Tortajada, C. (2016). Nongovernmental organizations and influence on global public policy. Asia and the Pacific Policy Studies, 3(2), 266-274.

Tengö, M., Brondizio, E. S., Elmqvist, T., Malmer, P., \& Spierenburg, M. (2014). Connecting diverse knowledge systems for enhanced ecosystem governance: The multiple evidence base approach. Ambio, 43(5), 579-591.

United Nations. (2015). Transforming our world: The 2030 agenda for sustainable development (No. A/RES/70/1). New York, NY: United Nations.

Wiener, A. (2007). The dual quality of norms and governance beyond the state: Sociological and normative approaches to 'interaction.' Critical Review of International Social and Political Philosophy, 10(1), 47.69

Wiener, A. (2014). A theory of contestation. Heidelberg: Springer.

Zelli, F., Gupta, A., \& van Asselt, H. (2013). Institutional interaction at the crossroads of trade and environment: The dominance of liberal environmentalism? Global Governance: A Review of Multilateralism and International Organizations, 19(1), 105-118.

\section{About the Authors}

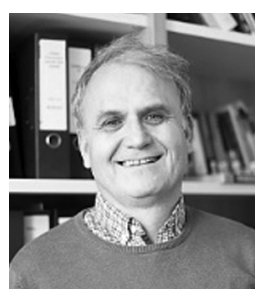

Helmut Breitmeier is Professor of International Relations at Justus Liebig University Giessen, Germany. $\mathrm{He}$ is member of the Executive Board of the Center for international Development and Environmental Research. His areas of expertise involve global governance, global norms and sustainability politics. He is Co-Principal Investigator of the SDGnexus Network which is committed to promoting the Agenda 2030 for sustainable development. The SDG-project is supported by the DAAD with funds of the German Federal Ministry for Economic Cooperation.

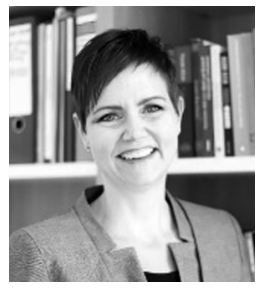

Sandra Schwindenhammer is Assistant Professor of International Relations at Justus Liebig University Giessen, Germany. She is co-principal investigator for the collaborative research project 'SUSKULTDevelopment of a Sustainable Cultivation System for Food in Resilient Metropolitan Regions' (2019-2022) funded by the German Federal Ministry of Education and Research and member of the Center for international Development and Environmental Research at Justus Liebig University Giessen. Her areas of expertise involve global norms, norm entrepreneurship, and agri-food and sustainability politics. 


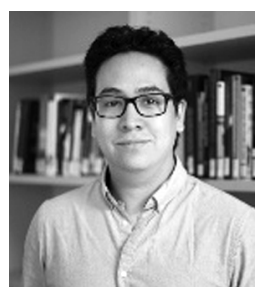

Andrés Checa is Research Assistant and PhD Candidate at Justus Liebig University Giessen, Germany. His work focuses on global norms and global environmental governance, especially in the field of agrifood and peace studies.

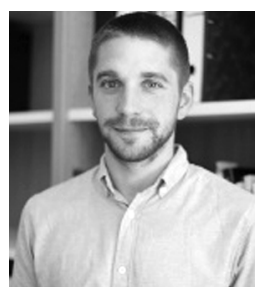

Jacob Manderbach is Research Assistant and PhD Candidate at Justus Liebig University Giessen, Germany. His work focuses on global norms and global environmental governance, especially in the field of agri-food and urban politics.

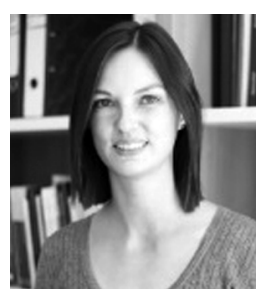

Magdalena Tanzer is Research Assistant and PhD candidate at Justus Liebig University Giessen, Germany. Her work focuses on global norms and global environmental governance, especially in the field of agri-food politics and food systems. 